\title{
ASSESSMENT OF THE INTERVAL HEAT FLOW AND THERMAL RESISTANCE AT THE FALTU-1 WELL, BORNO BASIN, NE NIGERIA
}

S. ALI AND K. MOSTO-ONUOHA

(Received 3 March 2021; Revision Accepted 15 April 2021)

\begin{abstract}
The heat flowing through horizons in the Faltu-1 well, Borno Basin, NE Nigeria was calculated from their thermal conductivities and geothermal gradients with the aim of determining whether or not it is uniform, and if not, the depths where it is diverted, and the possible heat diversion process. The interval heat flow was assessed to be non-uniform. While fluid convection is adjudged to be the major heat diversion mechanism within the Chad Formation with minor heat refraction, the reversed is adjudged to be the situation for the underlying Kerri Kerri Formaton within which increasing sand content with depth is also predicted, with the lower interval predicted to be the Gombe Formation. Patterns of disruptions to the vertical heat flow within the Fika Formation were inferred to suggest rhythmic bedding of shale and sand beds that could serve as both source and reservoir rocks. Magmatic intrusions that impacted the maturation of organic matter into oil and gas also provided necessary entrapment structures and possible migration pathways. The Gongila and Bima Formations each has single disruption of the heat flows that are attributed to refraction. In the case of the Gongila Formation, the disruption is between the early-deposited more sandy and laterdeposited more shaley lithologies in the marine transgression of the area, while in the case of the Bima, it is between the more shaley Upper and more sandy Middle Bima Formations. Analysis of the Bullard plots also revealed disruptions to the vertical heat flow that are attributed either to convecting fluids or to heat refraction and diffraction. Two such disrupting heat advections were identified within the Chad Formation with the first being attributed to convection, while the other is attributed to a combination of both. Two similar disruptions for the Kerri Kerri Formation were attributed largely to lithological variations with minor contributions from convection of fluids. While unable to discern the rhythmic bedding, the five disruptions of the Bullard plot for the Fika Formation and one each for the Gongila and Bima Formations were interpreted to indicate similar features inferred from interval heat flow plots.
\end{abstract}

KEYWORDS: Interval heat flow, heat convection, heat diffraction, thermal resistivity, shaliness

\section{$1.0 \quad$ INTRODUCTION}

The surface heat flow gives an indication of the total vertical heat flow through the underlying rock formations. At the Faltu-1 well site, this has been estimated to lie between 77.41 and $97.14 \mathrm{~mW} \mathrm{~m}^{-2}$ (Ali, 2016). The interval heat flow on the other hand, reveals the vertical heat flowing through intervals of the underlying rocks, and is therefore diagnostic of several non-vertical heat advection processes. This includes the heat that may be carried by laterally advecting fluid, as well as heat refracted due to thermal conductivity differences between lithologies and heat diffracted due irregular boundaries between stratas. Interval heat flow is the product of the interval thermal gradient by the interval thermal conductivity, and differs from surface heat flow which is the product of the thermal gradient in the subsurface by the thermal conductivity. The variations of interval heat flow, besides indicating that the flow of heat has lateral component alongside the vertical flow, may also indicate thermal conductivity differences arising from lithological variations. This paper assesses interval heat flow at the Faltu-1 well site (Fig. 1), northern survey area, Borno Basin, with the aim of revealing the influence of fluid flow including hydrologic flow, and the influence of lithologic variations including igneous intrusions.

The thermal resistance, $R$, of a sequence of beds expresses the resistance of the beds to the flow of heat and is defined as the sum of the ratios of the beds thicknesses, $\Delta z_{i}$, to their thermal conductivities, $\lambda_{i}$, that is $R=\Sigma \Delta z / \lambda_{i}$ (Bullard, 1939). The rate of change of temperature, $\partial T$, with change in the thermal resistance, $\partial R$, in a drilled hole will remain constant, $Q_{o}$, except if heat, $A(z)$, is removed or added between the surface and the depth $z$, that is:

\footnotetext{
S. Ali, Department of Physics, Abubakar Tafawa Balewa University, Bauchi, Nigeria

K. Mosto-Onuoha, Emeretus Chair, Department of Geology, University of Nigeria, Nsukka, Nigeria
} 
$\left(\frac{\partial T}{\partial R}\right)_{z}=Q_{o}-\int_{0}^{z} A(z) \partial z$

The plot of temperature against thermal resistance, called the Bullard plot, would have a constant slope equal to $Q_{0}$ except at depth segments with heat advection. Deviations from this constant slope have been attributed to climatological factors, to the rate of sedimentation or erosion and to the migration of ground water as well as other hot fluids, although poor data quality may also be a cause (Beards more and Cull, 2001). The paper also assesses the thermal resistances of the geologic formations encountered in the same well with the aim of revealing intervals where additional advection of heat occurs and compares these with those from the assessment of the interval heat flow.
Nigeria. This system is surrounded by the Pan African mobile belt, comprising the Benin-Nigeria Basement Complex, the Tuareg Shield and the AdamawaCameroun Basement. Cratchley (1960) delineated the Nigerian sector into three sub-basins prosperous for hydrocarbons exploration. These are separated from each other (Fig. 1) by the Arege-Marte High, the Bama Ridge, the Maiduguri and the Gubio Highs (GeoEngineering International, 1994; Obi, 1996) and are known as the Northern (Lake Chad), Western (Gubio) and Southern (Maiduguri) survey areas.

The Bima Formation is the basal unit found in the Basin (Fig. 2). The deposition of this sequence of sandstones, mudstones and occasional shales of variable texture, colour and structure (Carter et al., 1963) began in the Aptian to Albian (Genik, 1992) unconformably on the baseme

\subsection{GEOLOGIC SETTING}

The Borno Basin is the Nigerian sector of the Chad Basin. It is one of several basins within the West and Central African Rift System, (Genik, 1992) and spreads around the republics of Niger, Chad, Cameroon and

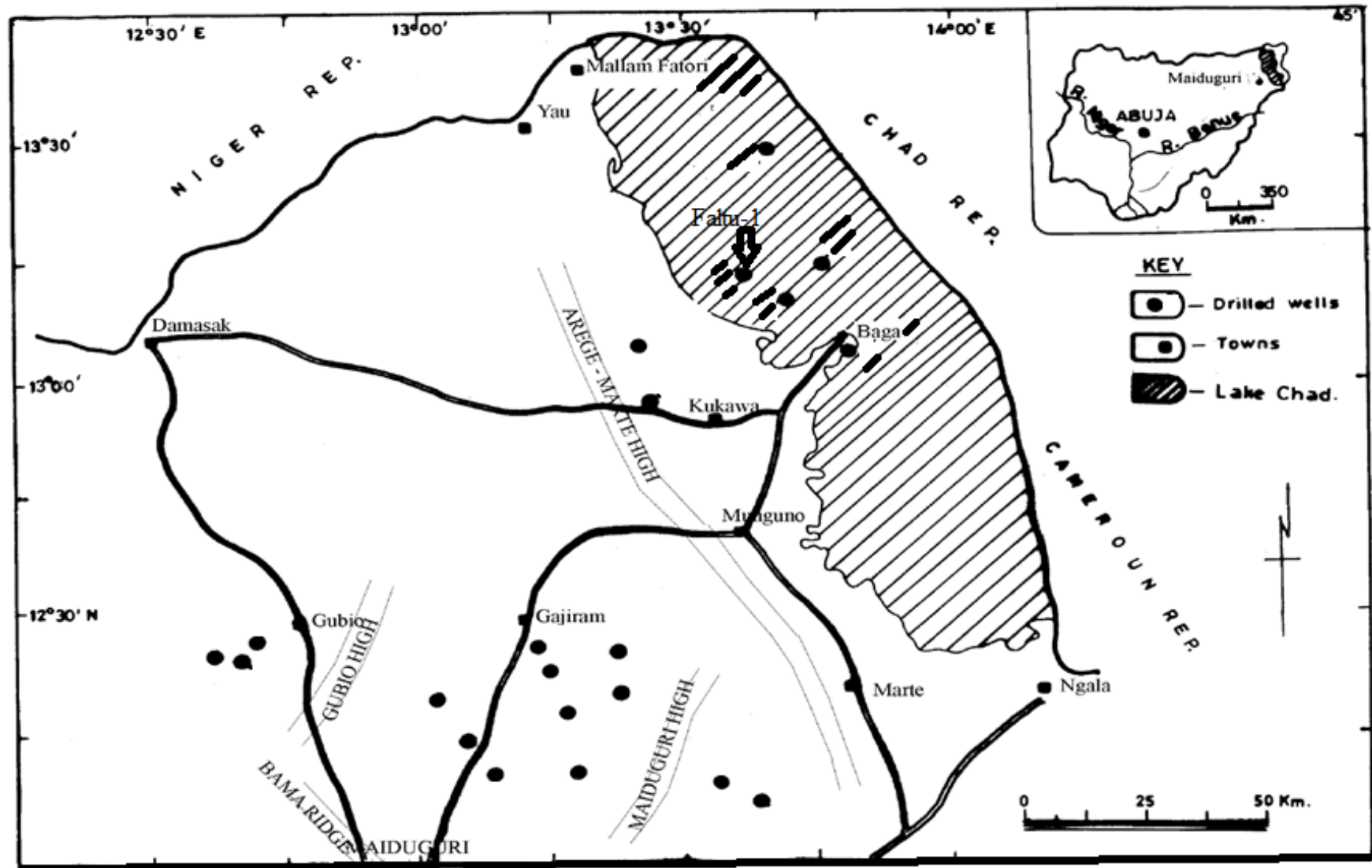

Fig. 1. Location of the Faltu-1 well in the northern survey area of the Nigerian sector of the Borno Basin. 


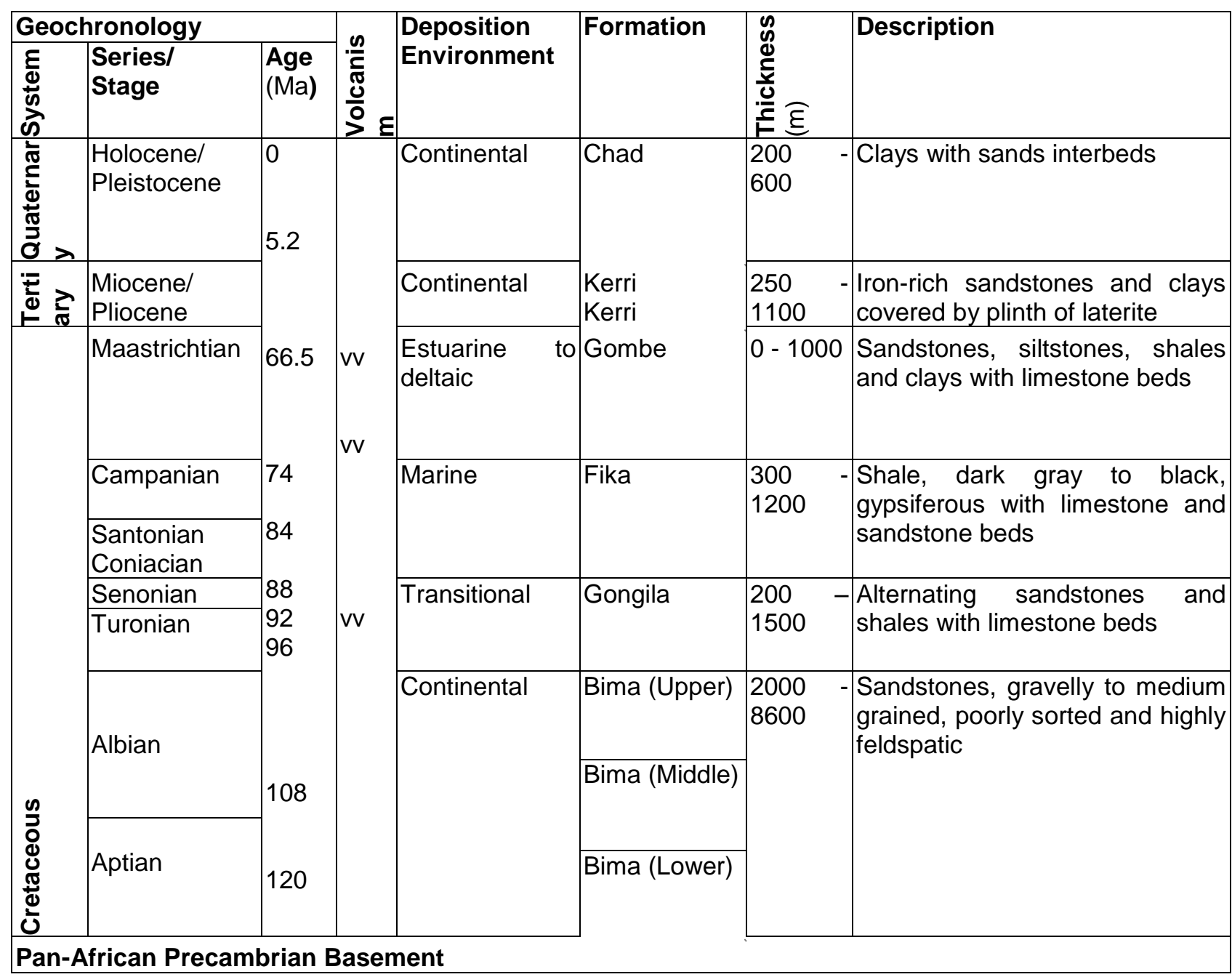

Fig. 2. Generalised stratigraphic column for the Basin (Modified after Avbovbo et al., 1986).

complex. Up to $5 \mathrm{~km}$ of this formation have been encountered in drilled holes while interpreted seismic sections suggest 7 to $8 \mathrm{~km}$ depth extent (Avbovbo et al., 1986). Mudstone and shale horizons are more frequent within the shallower parts (GeoEngineering International, 1994), while sandstones horizons are suggested to form possible reservoirs, while the shale horizons form possible entrapment structures (Samaila, 2007).

Overlying the basal Bima is the transitional Gongila Formation, a sequence of fine- to very fine-grained sandstone beds with fair porosity and shale beds, with the beds becoming more sandy towards the base. Its deposition began between the late Albian to the early Cenomanian in a bi-directional marine transgression across the Tethys from the north and from South Atlantic through the Benue trough to the south (Reyment, 1980; Allix et al., 1981; Benkhelil and Robineau, 1983; Genik, 1992). Fossil-rich limestone horizons yielding lower Turonian age also occur towards the base. The formation has abundance of the interbedding of the source, reservoir, seal and cap rocks to form the structures necessary for the entrapment of hydrocarbons. The kerogen type within these source rocks is also a mixture of types II and III. The maturity of the sediments within these rich horizons varies from middle- to post-matured (GeoEngineering International,
1994). A wholly marine sequence, the Fika Formation, consisting of a sequence of blue-black shales thin nonpersistent limestone horizons, conformably overlies the Gongila. This was deposited at the height of the marine transgression of the area and may be up to $1000 \mathrm{~m}$ thick. The end of the transgression was accompanied by the deposition of up $1000 \mathrm{~m}$ of a sequence of sandstone, shale, ironstone and coal beds called the Gombe Formation over the Fika in an estuarine to deltaic environment over a minor unconformity. The occurrence of the formation is thought to be restricted to the southwestern part of the basin. A sequence of flat lying grits, sandstones and clays, deposited by about the late Maastrichtian to the end of Paleocene, that appear to be derived from a terrain of Cretaceous sedimentary rocks, the Kerri Kerri Formation, overlie the Gombe Formation at angular unconformity. The Chad Formation, a sequence of massive and gritty clays, loosely to uncemented sands and silts overlies the Kerri Kerri Formation at a minor unconformity suggested by seismic data (Avbovbo et al., 1986). Its deposition started between middle Neogene to Quaternary times (Carter et al., 1963) and lasted till Recent times.

Magmatic intrusions with thicknesses ranging between 5 and $220 \mathrm{~m}$ that may be either doleritic or gabbroic have been identified in the basin (GeoEngineering International, 1994). Such intrusions were generated 
when continents rift, and hot asthenospheric mantle melts due to decompression and passively rise beneath stretched and thinned lithosphere zones (White \& McKenzie, 1989). Using both 2- and 3-D seismic data, Suleiman et al. (2017) have mapped saucer-shaped and strata-concordant sills and volcanic plugs geometries in the basin, and based on seismic stratigraphy and host rocks enhancements, their emplacements have been dated to corresponding to the timing of major plate boundary interactions, namely, Early Cretaceous (Albian to Cenomanian; c. $120 \mathrm{Ma}$ ), Late Cretaceous (Santonian to early Campanian; c. $83 \mathrm{Ma}$ ) or Cenozoic (Miocene; c. $22 \mathrm{Ma}$ ). These intrusives have gamma ray intensities of between 20 and $50 \mathrm{API}$, resistivities of more than 20 ohm-metre, bulk densities of 2700 to $2900 \mathrm{~kg} \mathrm{~m}^{-3}$ and interval transit times of $230 \mu \mathrm{s} \mathrm{m}^{-1}$ and less. Intrusives bodies have also been reported in wells drilled around the Lake Chad in the neighbouring Chad Republic (Genik, 1993).

The Borno Basin is semi-arid, with low rainfalls, and gently dips towards the lake. The lake drains whatever little surface water that exists in the area, but this still constitutes only about $10 \%$ of the lake waters, the remaining coming from underground flows, with the Chad Formation providing most of underground water to the lake. Three widely extensive aquifers have been mapped within this formation in the basin (Barber and Jones, 1960; Miller et al., 1968; Oteze and Fayose, 1988). These aquifers are composed of sands whose cementation varies from highly to loosely cemented, thickness varying from 45 to about $380 \mathrm{~m}$, grain size ranging from fine to coarse, and with thin intercalations of clays. Thick clay and sandy clay beds separate the aquifers. Some water is also tapped from the Kerri-Kerri Formation particularly at locations where the water table is shallow or in perched aquifers.

\subsection{METHODOLOGY}

The Faltu- 1 is one of over twenty one wells drilled by the Nigerian National Petroleum Company in the Borno Basin as part of its petroleum exploration and drilling programme. It is located N1,459,529.52 and E349,963.82 utm. The thicknesses of the formations penetrated in the well were obtained from the report of GeoEngineering International (1994). Ali et al. (2003) using air temperature data have estimated the ground surface temperature in Maiduguri to be $36^{\circ} \mathrm{C}$. This value is adopted in this study for the computation of geothermal gradients. Ali et al. (2005) have also corrected bottom hole temperatures from twenty one oil exploration wells drilled in the Borno Basin. Based on the nature and quality of data, the temperatures corrected by the method of Leblanc et al. (1981) and those corrected by the method of Horner plot (1951) respectively were adjudged to define the lower and upper limits of temperatures in the basin. Based on these, formational geothermal gradients in Table 1 were calculated. Ali and Orazulike (2011) have estimated the thermal conductivities of the drilled horizons in the Faltu1 well at the intervals of $2 \mathrm{~m}$, and these are also used in this study.

\subsection{RESULTS AND DISCUSSIONS \\ 4.1 Interval Heat Flow}

The interval thermal conductivity data was multiplied with the limiting formational average thermal gradients to obtain the interval heat flows. Figures 3 give the trends of the lower (black lines) and upper (gray lines) interval heat flow limits with depth in the five formations. The plots indicate that vertical conduction of heat at the well site is not uniform, but disrupted at several depth intervals.

Within the topmost Chad Formation which extends to the depth of $484 \mathrm{~m}$, the plot of interval heat flow with depth, (Fig. 3a) reveals three intervals, $50-156,156-$ 396 and $396-484 \mathrm{~km}$ that have uniform heat flows as listed in Table 1. With limiting surface heat flow of 77.41 and $97.14 \mathrm{~mW} \mathrm{~m}^{-2}$, between 49.51 and $139.95 \mathrm{~mW} \mathrm{~m}^{-2}$ of heat is prevented from reaching the surface vertically. This is believed to be partly refraction and diffracted and partly convected by hydrologic flow. The top interval also retains between 7.55 and $14.09 \mathrm{~mW} \mathrm{~m}^{-2}$ of the heat vertically transmitted from the middle interval, and this is believed to be accounted from thermal conductivity, suggesting a more shaley interval underlying a more sandy one. Between 10.45 and $18.7 \mathrm{~mW} \mathrm{~m}^{-2}$ of heat flowing from the bottom interval is laterally taken away in the middle interval. Although thermal conductivity change could generate vertical heat flow disruption of similar magnitude, it is believed that the heat flow disruption is mainly hydrologic flow induced. Hydrologic flow is believed to constitute $90 \%$ of the lake waters (Barber and Jones, 1960). To depress vertical heat flow by that magnitude, water of specific heat capacity $4.2 \mathrm{~J}$ $\mathrm{kg}^{-1}{ }^{\circ} \mathrm{C}^{-1}$ would have to flux through a formation having a lower limit temperature gradient of $30.96{ }^{\circ} \mathrm{C} \mathrm{km}^{-1}$ at a rate of $0.15 \mathrm{~kg} \mathrm{~m}^{-2} \mathrm{~s}^{-1}$ or for an upper limit temperature gradient of $52.42{ }^{\circ} \mathrm{C} \mathrm{km}^{-1}$ at a rate of $0.12 \mathrm{~kg} \mathrm{~m}^{-2} \mathrm{~s}^{-1}$. These fluxes favorably compare with borehole hydraulic discharge of between 12.8 and 1.4 litres $\mathrm{s}^{-1}$ determined for the middle aquifer (Yusuf et al., 2014) of the Borno Basin. This disruption to vertical flow of heat is also believed to have received minor contribution from strata of subtle thermal conductivity differences.

The plot of the interval heat flow with depth for the Kerri Kerri Formation (Fig. 3b) shows three heat flow segments having limiting values that increase with depth as listed in Table 1. Although fluid convection may be contributing to the deflection of the vertical heat conduction, we believe this contribution is minimal. The major activities deflecting vertical heat flow are refraction, arising from thermal conductivity differences between the strata, and diffraction, arising from the structural dispositions. This suggests that the increase in heat flow with depth is primarily indicative of increasing sand dominance towards the base of the formation. The higher heat flow for the bottom strata in comparison to the two overlying ones suggests a sandstone-ironstonedominated rather than grits-sandstone-clay dominated sequence, and may therefore be the Gombe Formation, previously presumed not to have laterally extended far north towards the Lake Chad, rather than the Kerri Kerri Formation. 
The plot of the interval heat flow for the Fika Formation (Fig. 3c) reveals subtle variations that suggest rhythmic bedding, as well as major disruptions that are attributed to magmatic intrusions. The rhymic bedding, occurring between the depths of 1384 and $1838 \mathrm{~m}$, is believed to majorly indicate thermal conductivity variation between interbedding lithologies, with minor lateral removal of heat by possible pore fluids. The likely interbedding lithologies are shale and sand beds. These constitute hydrocarbon source and reservoir rocks, making the depth interval a favourable exploration target. The three major heat flow disruptions appear to be of two types. The first type occurred at the two depth ranges of 1274 to 1384 and 1838 to $1900 \mathrm{~m}$, and has limiting interval heat flow values of 103 and $111 \mathrm{~mW} \mathrm{~m}^{-2}$. The second type occurred at the depth range of 1964 to $2060 \mathrm{~m}$ and has limiting interval heat flow values of 113 and $122 \mathrm{~mW}$ $\mathrm{m}^{-2}$. This suggests two episodes of the intrusion events in line with the work of Suleiman et al. (2017).

Table 1. Geothermal gradients $\left({ }^{\circ} \mathrm{C} \mathrm{km}^{-1}\right)$, Interval Heat flow, IHF and heat advection limits, $A(z),\left(\mathrm{mW} \mathrm{m}^{-2}\right)$ derived from Bullard plots in segments of formations. Surface heat flow at the well site is between 77.41 and $97.14 \mathrm{~mW} \mathrm{~m}^{-2}$. Positve $A(z)$ indicate removal of heat while negative ones indicate heat addition.

\begin{tabular}{|c|c|c|c|c|c|c|c|c|c|}
\hline \multirow[t]{3}{*}{ Formation } & \multirow{3}{*}{$\begin{array}{l}\text { Depth } \\
\text { Interval }(m)\end{array}$} & \multirow{2}{*}{\multicolumn{2}{|c|}{$\begin{array}{l}\text { Geothermal } \\
\text { gradient limits }\end{array}$}} & \multirow{2}{*}{\multicolumn{2}{|c|}{ IHF limits }} & \multicolumn{4}{|c|}{ Bullard plot } \\
\hline & & & & & & \multicolumn{2}{|c|}{ Lower limit } & \multicolumn{2}{|c|}{ Upper limit } \\
\hline & & Lower & Upper & Lower & Upper & $Q_{0}$ & $A(z)$ & $Q_{o}$ & $A(z)$ \\
\hline \multirow[t]{3}{*}{ Chad } & $50-156$ & & & 126.65 & 237.09 & 150.0 & -19.6 & 238.6 & 5.2 \\
\hline & $156-396$ & 30.96 & 52.42 & 119.10 & 223.00 & 117.3 & 13.1 & 168.2 & 75.6 \\
\hline & $396-484$ & & & 129.55 & 241.70 & 130.4 & - & 243.8 & - \\
\hline \multirow[t]{3}{*}{ Kerri Kerri } & $484-754$ & & & 66.11 & 77.16 & 125.0 & 10.5 & 235.3 & 2.2 \\
\hline & $754-940$ & 11.73 & 14.08 & 70.78 & 83.72 & 118.7 & 16.8 & 217.8 & 19.7 \\
\hline & $940-1274$ & & & 71.74 & 84.84 & 135.5 & - & 237.5 & - \\
\hline \multirow[t]{6}{*}{ Fika } & $1274-1384$ & & & 101.92 & 109.67 & 121.6 & -39.8 & 114.3 & -27.3 \\
\hline & $1384-1838$ & & & 77.59 & 83.80 & 86.4 & -4.6 & 85.7 & 1.3 \\
\hline & $1838-1900$ & & ס 25 & 103.34 & 111.47 & 104.8 & -23.0 & 118.0 & -31.0 \\
\hline & $1900-1964$ & 32.50 & 35.38 & 80.63 & 87.10 & 75.0 & 6.8 & 107.1 & -20.1 \\
\hline & $1964-2060$ & & & 113.59 & 122.53 & 111.1 & -29.3 & 120.0 & -33.0 \\
\hline & $2060-2216$ & & & 81.45 & 87.96 & 81.8 & - & 87.0 & - \\
\hline \multirow[t]{2}{*}{ Gongila } & $2216-2500$ & 2120 & 2365 & 56.36 & 64.52 & 57.1 & 5.4 & 65.6 & 5.0 \\
\hline & $2500-2790$ & $21 . \angle 0$ & 23.65 & 59.95 & 68.60 & 62.5 & - & 70.6 & - \\
\hline \multirow[t]{2}{*}{ Bima } & $2790-3030$ & $270 ?$ & 2061 & 102.62 & 100.44 & 102.9 & 5.8 & 102.3 & 6.4 \\
\hline & $3030-3160$ & 27.92 & 30.61 & 107.80 & 105.42 & 108.7 & - & 108.7 & - \\
\hline
\end{tabular}


S. ALI AND K. MOSTO-ONUOHA

(a)

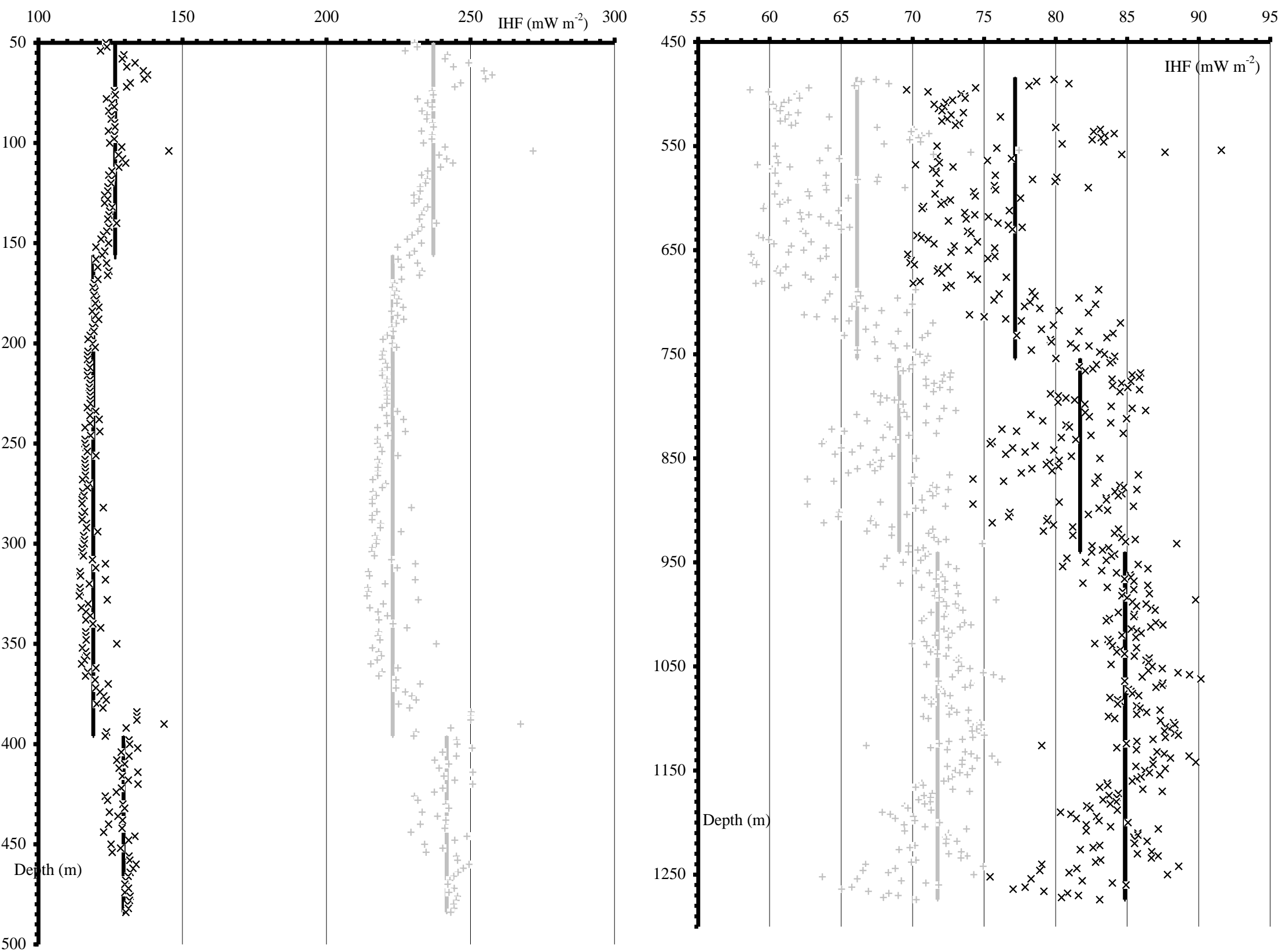


$80 \quad 100 \quad$ IHF $\left(\mathrm{mW} \mathrm{m}^{-2}\right) \quad 120$

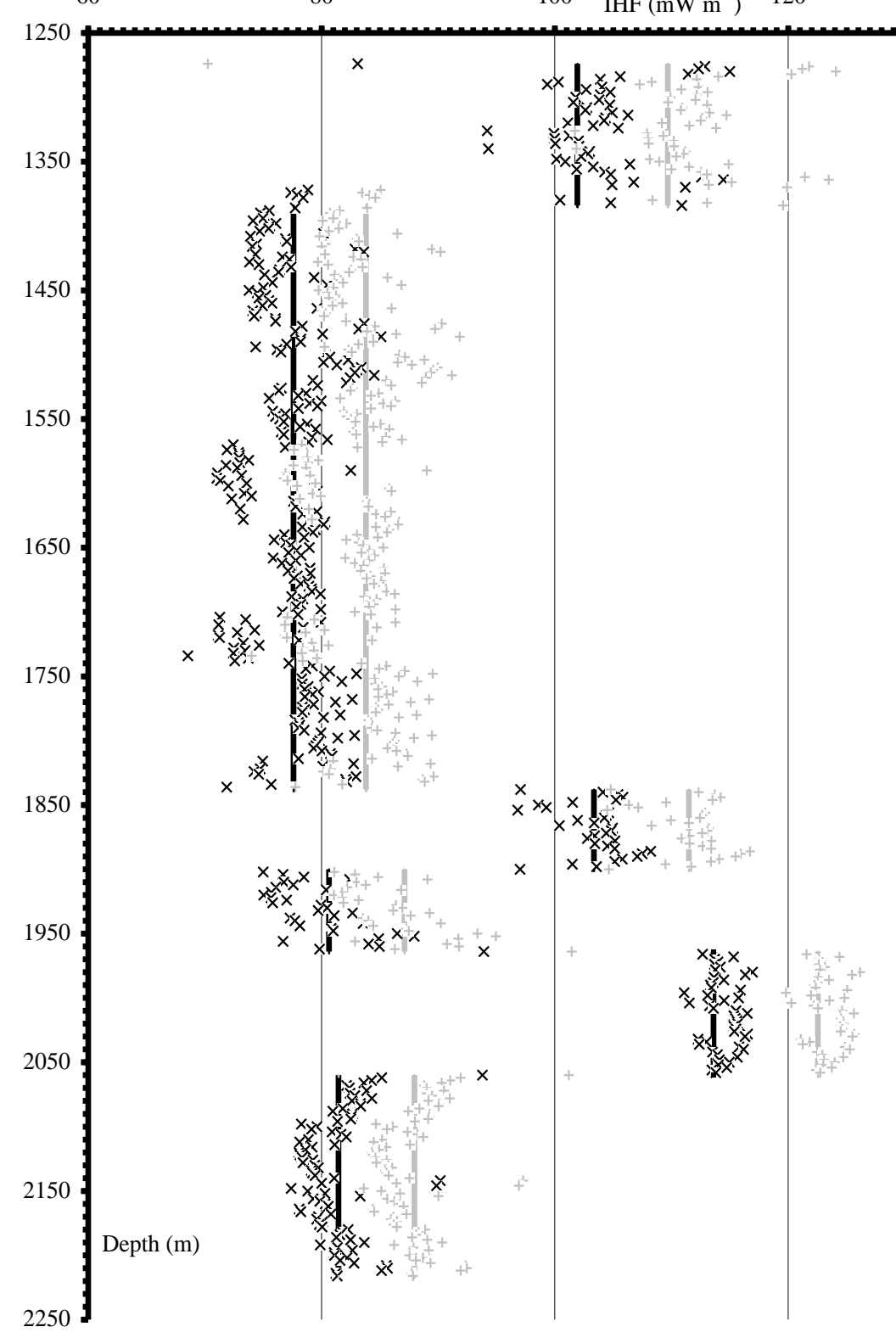

(d)

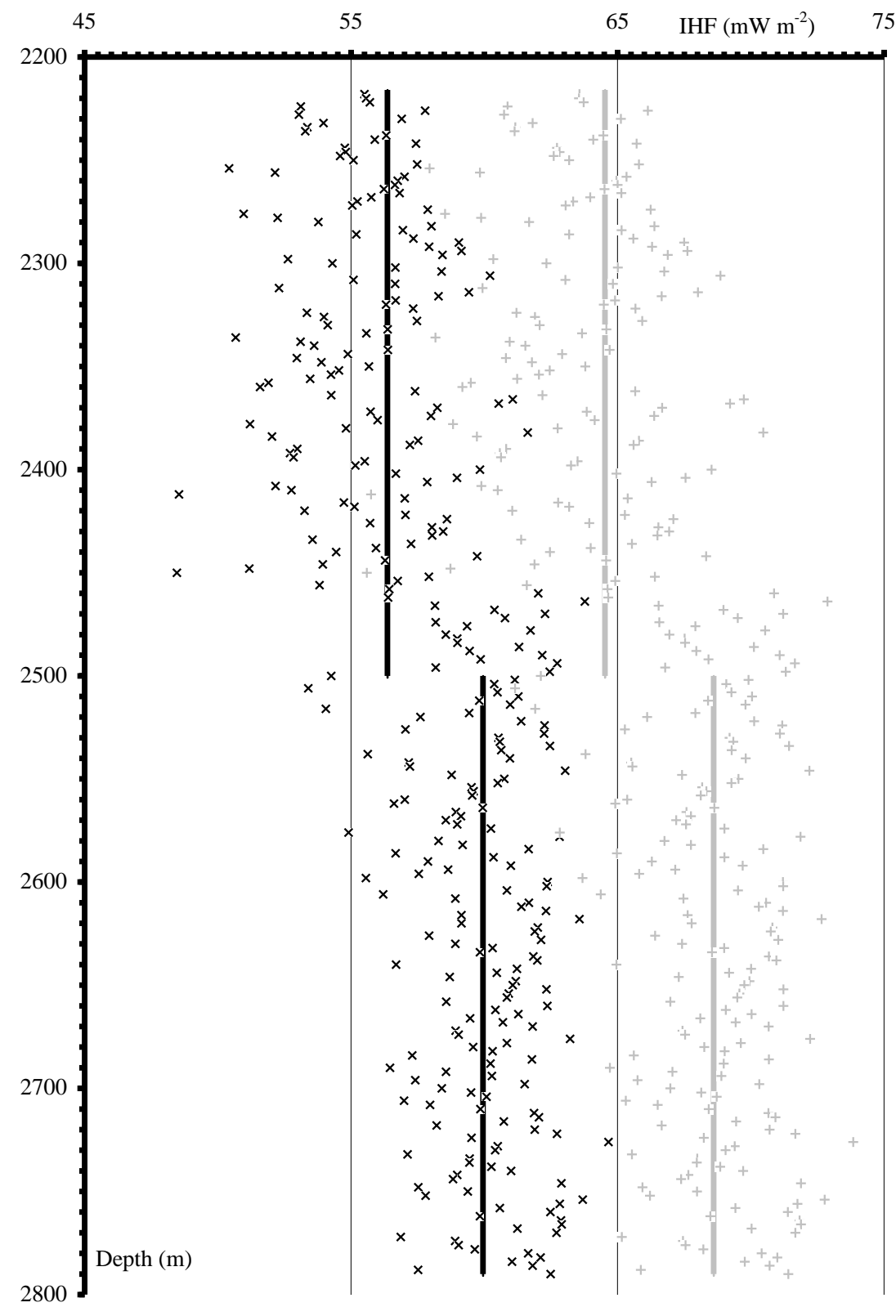




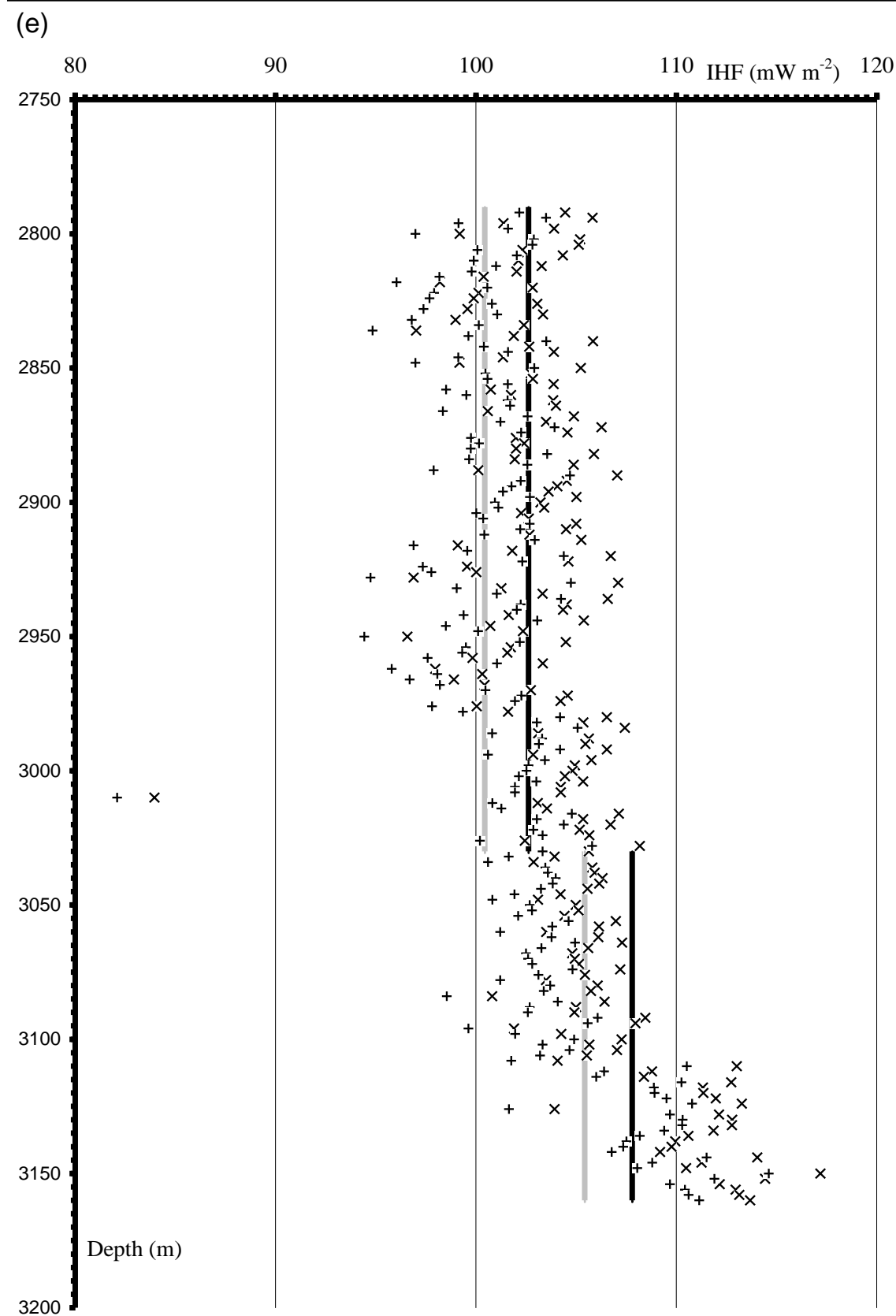

Fig. 3. Trends of lower limit (black) and upper limit (grey) interval heat flows between drilled horizons in (a) the Chad, (b) the Kerri Kerri, (c) the Fika, (d) the Gongila and (e) the Bima Formations at the Faltu-1 well. 
The maturation of organic matter in oil and gas in sedimentary basins is impacted by the heat released by intruding magmatic bodies (White \& McKenzie, 1989; Ali et al. 2005). The time lapse for this varies from as low as $10 \mathrm{Ma}$ to over $500 \mathrm{Ma}$ depending on the subsidence rate, the geothermal gradients of the various strata and the sulfur content of the organic matter (Siever, 1983; Ejedewa and Coker, 1984; Wood, 1988; Hunt et al., 1991; Armstrong et al., 1996). The generation, ascend, emplacement and subsequent cooling to ambient temperatures of magmatic intrusions depend on the lithology of the intruding magma, that is, whether granitic or basaltic, the viscosities of the intruding magma and of the upper crustal rocks through which the magma ascend. It also depends on the presence of circulating waters both in the magma and the host rocks (Mahon et al., 1988; Clemens and Mewer, 1992; Petford et al., 1993, 1994; and Clemens et al., 1997; Hardee, 1982; Brown, 1987). This takes a few days for thin basaltic magmas (Webber et al., 1999) and up to 10 Ma for granitic magmas (Petford, 1996; Jackson et al., 2003). The time interval over which small basaltic bodies intrude into and cool within sedimentary sequences tend to be small or negligible in comparison to the time interval necessary for the maturation of organic matter in oil and gas within the same sequences. The impact of these intrusions is to alter the maturation process by the injection of a heat pulse which may push maturation from immature to matured stage or from matured to post-mature depending on the proximity between the source rock and the intrusion. The intrusion may also affect the migration pathway, providing a conduit along which generated hydrocarbons may move from source to reservoir rocks as well as provide capping and/or sealing structures suitable for the entrapment of hydrocarbons (White \& McKenzie, 1989). In these respected, the intrusion at the depths of 1274 to $1384 \mathrm{~m}$ would serve as cap rock while that at the depths of 1838 to $1900 \mathrm{~m}$ would serve as seal rock to the possible source and reservoir rocks located by 1384 and $1838 \mathrm{~m}$. Similarly, the possible reservoir rock between the depths of 1900 to $1964 \mathrm{~m}$ could be capped by the intrusion at the depth of 1838 to $1900 \mathrm{~m}$ and be sealed by the intrusion at the depth 1964 to $2060 \mathrm{~m}$. Magmatic intrusions also alter the physical properties of capping and sealing rocks, increasing the accumulation of stress which leads to the opening of fractures and activation and reactivation of faults that may influence permeability (Sydnes, et al. 2019).

Besides impacting maturation, the heat from magmatic intrusions, as well as that from normal burial and hydrothermal fluids, could initiate illite-smectite mineralisation process in sediments, increasing the proportion of illite layers with proximity from the intrusions (Esposito and Whitney, 1995). Similarly, when intrusions interact with hydrothermal fluids carrying high metal concentrations outward, skarn deposits are formed by the replacements of limestone, calcareous rocks, or dolomite to produce a variety of minerals including oxide minerals such as magnetite, sulfide minerals such as chalcopyrite, silicate minerals such as epidote, or the tungstate minerals scheelite. Associated with skarn deposits, which can be either massive and discordant, or stratiform and concordant, are such elements as tungsten, copper, molybdenum, iron, gold, tin, lead, zinc and silver (Bevins, 1994; Jamtveit et al.
2004; Richter et al. 2018; Zhang et al. 2020). Economics permitting, zones in the vicinity of magmatic intrusions may be mined for any occurring mineral when the oil is eventually exhausted or when the hole is dry.

Fig. 3d shows the plot of interval heat flow with depth within the Gongila Formation. Its reveals two segments with uniform heat flow values as listed in Table 1. The disruption of the vertical heat flow is believed to have resulted from lithological change rather than the advection of fluid. This probably represents a sandy lithology at the bottom followed by intercalation of more shaley and sandy lithologies deposited at the top as the bi-directional marine transgression event that affected the area progressed. Reservoir quality horizons are therefore more probable within the lower half of the formation while source rocks would be more probable in the upper half, and migration of hydrocarbons to the reservoirs downward. The scatter of points around the uniform heat flow suggests the removal of heat in direction beside the vertical, probably by fluid flowing in the more sandy lithologies that possess the necessary permeability. The plot for the Bima Formation, (Fig. 3e), also revealed two segments with limiting interval heat flows as listed in Table 1. The disruption of the flow of heat within the formation is believed to primarily indicate thermal conductivity change, and also to indicate fluid flow within the interstices of the permeable strata. The thermal conductivity change is believed to indicate the lithology change between the Upper and Middle Bima Formations, with the more shaley upper lithology having lower interval heat flow in comparison to the sandier lower lithology in agreement with GeoEngineering International, (1994), implying that reservoir type horizons are more probable within the lower formation, and migration is more probable from source rocks down to reservoirs located below.

\subsection{Thermal Resistance}

The Bullard plot for the Chad Formation (Fig 4a) indicate two heat flow deflections on the heat flowing through the lower lithology, and all three have slopes (heat flows) as listed in Table 1. The first of these deflections has limiting values of 13.1 and $75.6 \mathrm{~mW} \mathrm{~m}^{-2}$ over the heat flowing through bottom lithology that are both heat removals. In line with the inference proffered for the interval heat flow over the same interval, this deflection is also attributed to the flow of fluid. The second deflection has limiting heat advections -19.6 and $5.2 \mathrm{~mW}$ $\mathrm{m}^{-2}$, indicating both heat addition on the lower limit and removal on the upper limit and which are interpreted to suggest that the heat flow deflection is a result of thermal conductivity differences and fluid flow. Similarly, the Bullard plot for the Kerri Kerri Formation (Fig. 4b) indicate two heat flow deflections on that flowing through the bottom lithology, with all three having heat flows as listed in Table 1. The deflections are attributed largely to lithology variations between the lower lithology and the two overlying ones but with minor contributions from fluid flow. This also implies that the bottom lithology is sandier while the middle lithology is more shaley. Again, this is consistent with the inference proffered for the interval heat flow for the same formation.

The Bullard plot for the Fika Formation (Fig. 4c) revealed five heat flow deflections from that through the bottom lithology, and these have heat flows as listed in Table 1. The deflections are interpreted to indicate the 
effects, on the flow of heat, of the five lithologies over the basal lithology which was deposited at early stage of the late Albian to the early Cenomanian marine incursion of the area. This lithology is believed to be shaley on account of the comparatively low

heat flowing through it. The rapid outflows of heat in three of the five lithologies, located between the depths 1274 - 1384, 1838 - 1900 and 1964 - 2060 m, suggest that these represent magmatic intrusions, possessing higher thermal conductivities. This is also consistent with the inference proffered for the same intervals from the analysis of the interval heat flow. The interval between the depths of 1900 and $1964 \mathrm{~m}$ receives heat on the lower limit and transmits heat on the upper limit, and is thought to suggest a lithology possessing the ability to transmit fluid and hence heat in the lateral direction, and thus a possible reservoir. Similarly, the lithology between the depths of 1384 and $1838 \mathrm{~m}$, also suggest a possible reservoir.

Only single heat flow deflections are identified on the Bullard plots for the Gongila and Bima Formations (Figs. $4 \mathrm{~d}$ and e) over the heat flowing through their bottom lithologies, and these are listed in Table 1. The deflections are both attributed to lithology changes, with that from the plot for the Gongila Formation indicating variation from more sandy lithology at the base to more shaley one at the top as the bi-directional marine transgression of the area progressed (Reyment, 1980; Allix et al., 1981; Benkhelil and Robineau, 1983). Similarly, the deflection from the plot for the Bima Formation is attributed to the lithology change from the more sandy Middle Bima to the more shaley Upper Bima Formations, consistent with the inference proffered for the interval heat flow for the same formation and with observation of GeoEngineering International (1994). 
(a)

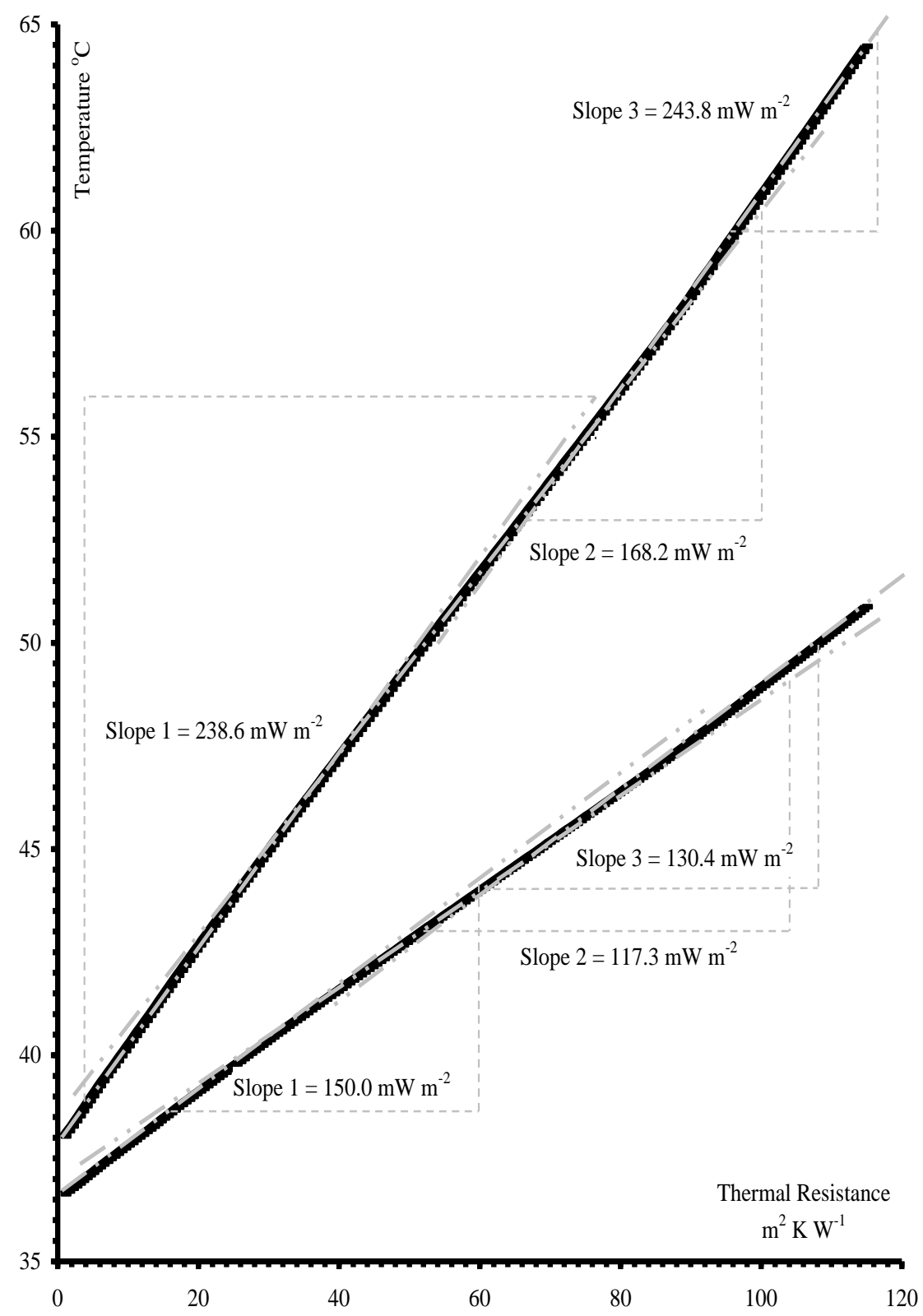

(b)

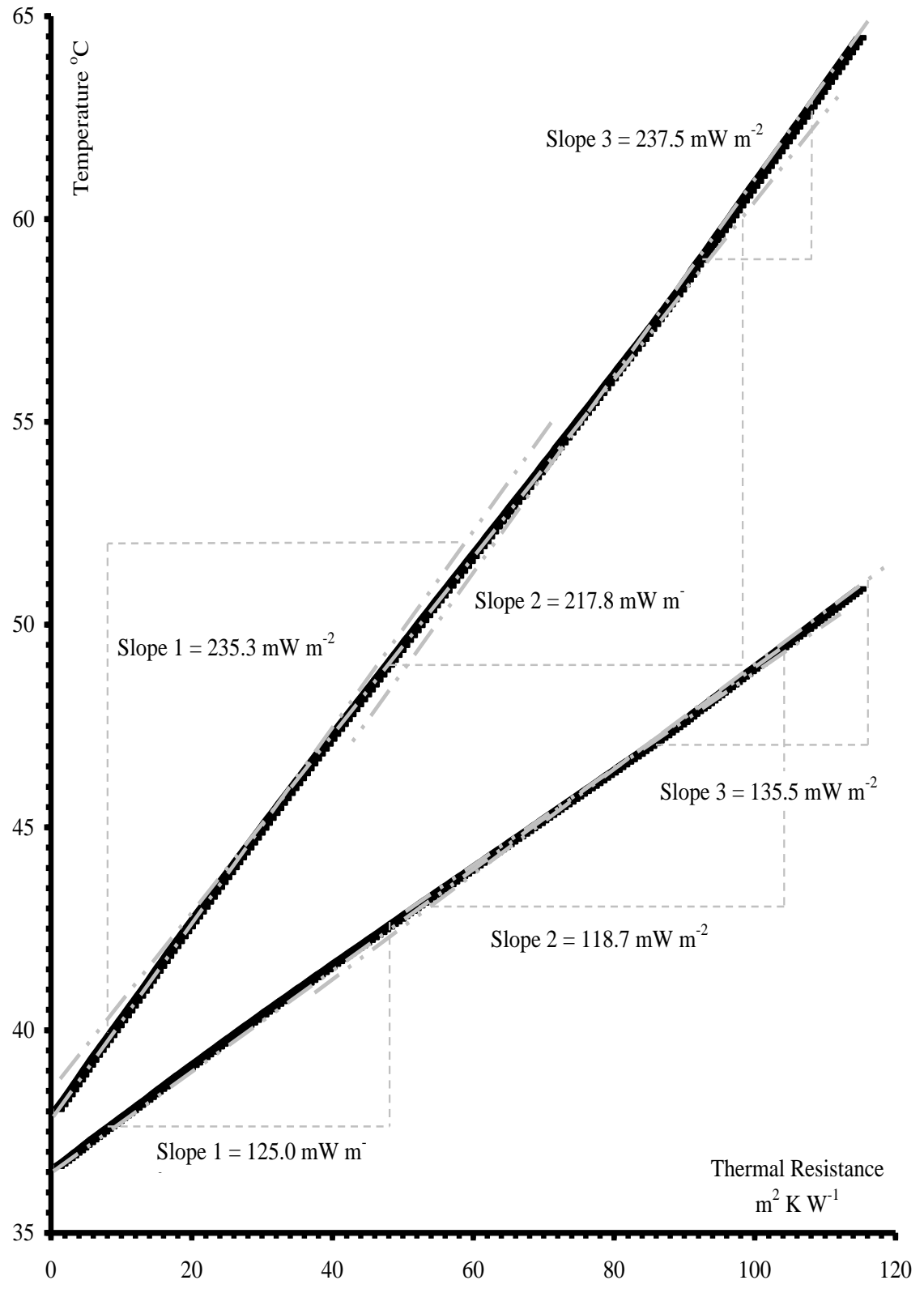




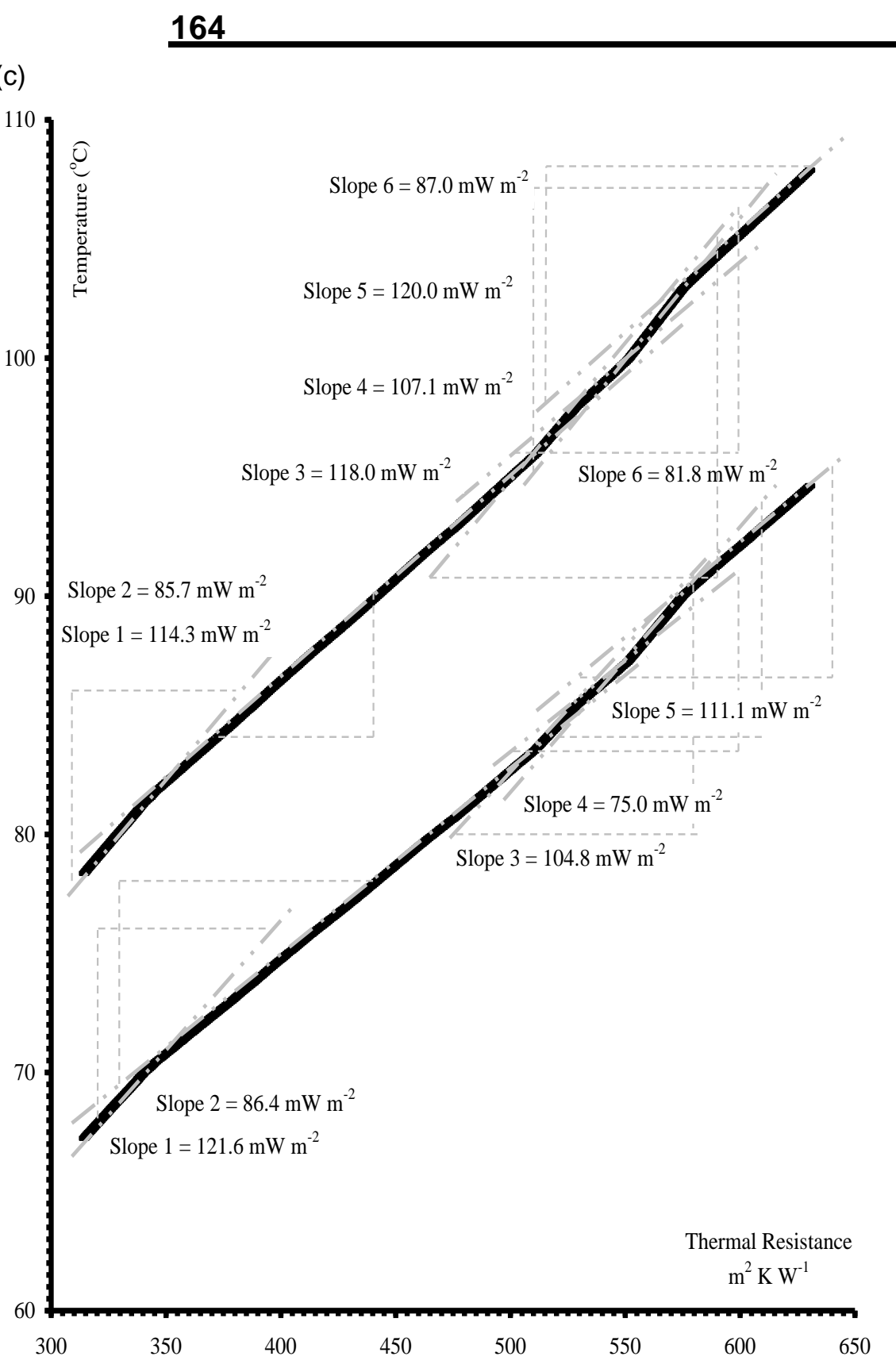

S. ALI AND K. MOSTO-ONUOHA

(d)

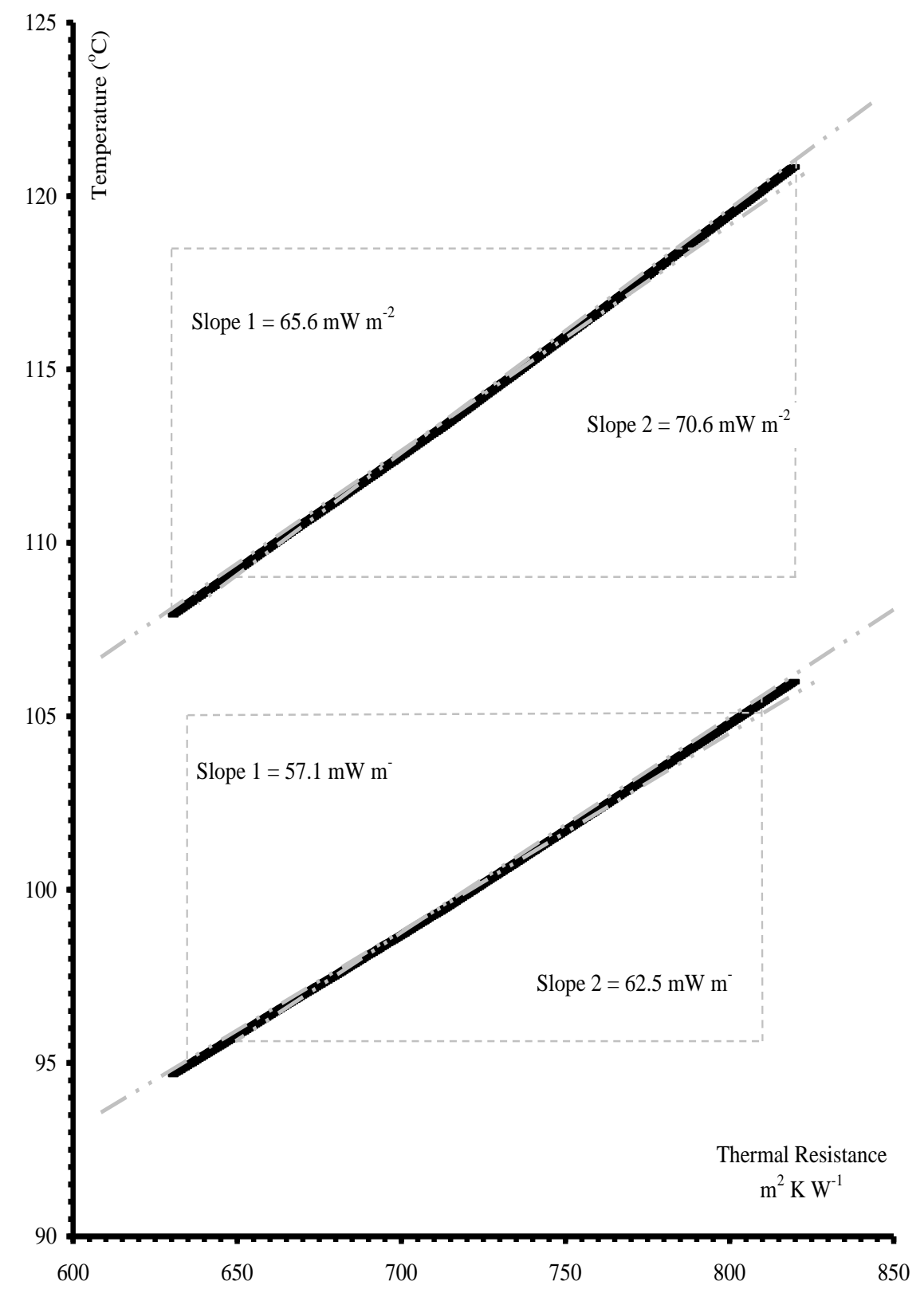


(e)

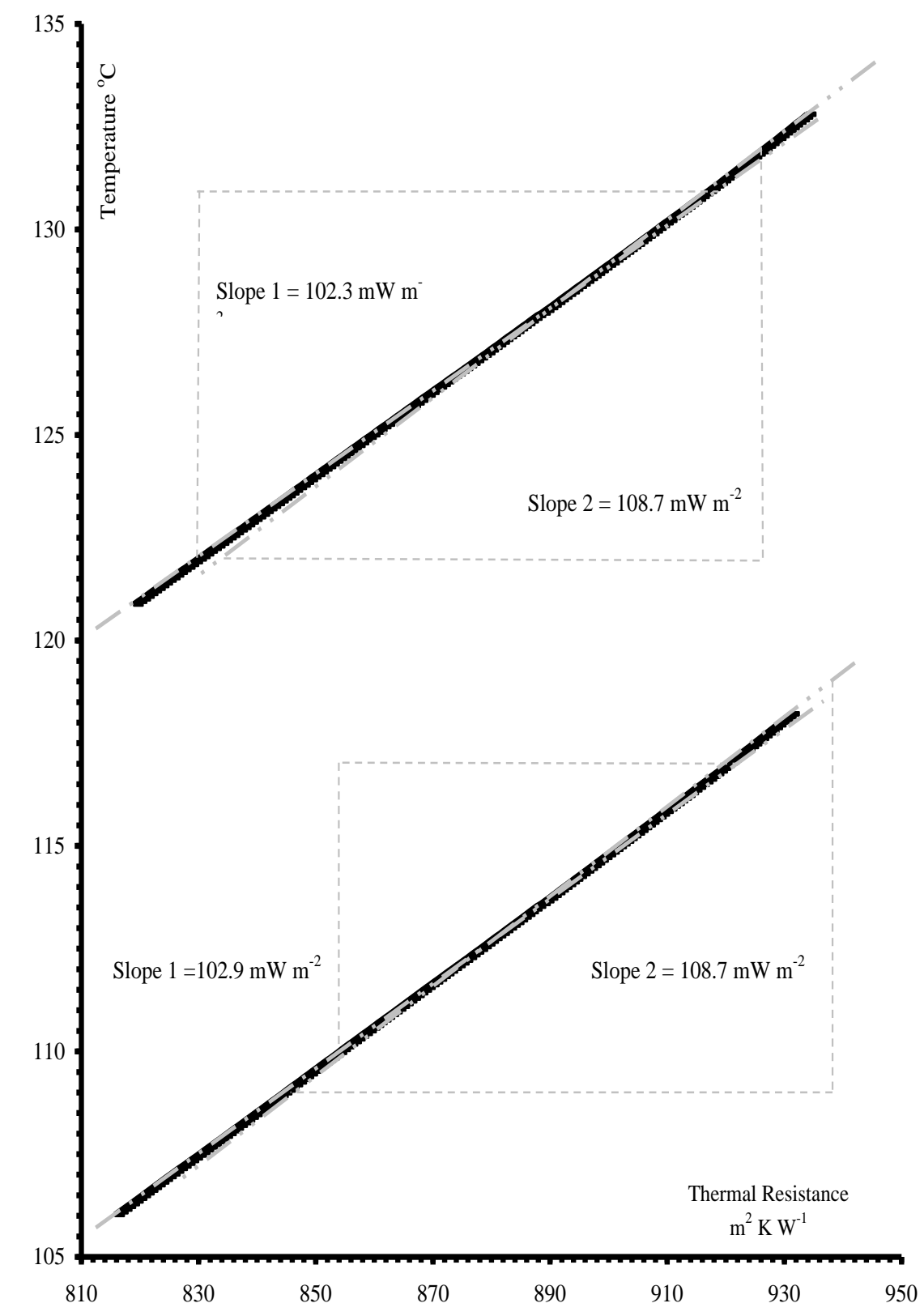

Fig. 4. Bullard plots for lower and upper limit temperatures versus thermal resistance for (a) the Chad, (b) the Kerri Kerri, (c) the Fika, (d) the Gongila and (e) the Bima Formations. Dash-dotted gray lines are fitted straight sections indicating heat flow segments. Dash gray lines indicate associated slopes highlighting heat flow the segments. 
Figure Captions.

Figure 1. Location of the Faltu-1 well in the northern survey area of the Nigerian sector of the Borno Basin

Figure 2. Generalised stratigraphic column for the Basin (Modified after Avbovbo et al., 1986).

Figure 3. Trends of lower limit (black) and upper limit (grey) interval heat flows between drilled horizons in (a) the Chad, (b) the Kerri Kerri, (c) the Fika, (d) the Gongila and (e) the Bima Formations at the Faltu-1 well.

Figure 4. Bullard plots for lower and upper limit temperatures versus thermal resistance for (a) the Chad, (b) the Kerri Kerri, (c) the Fika, (d) the Gongila and (e) the Bima Formations. Dash-dotted gray lines are fitted straight sections indicating heat flow segments. Dash gray lines indicate associated slopes highlighting heat flow the segments.

\subsection{SUMMARY/CONCLUSIONS}

The vertical conduction of heat through the five formations encountered in the Faltu-1 well, Northern survey area, Borno Basin, NE Nigeria was assessed to be non-uniform, receiving and transmitting unequal heat vertically, with the balance flowing laterally. Within the topmost Chad Formation, three depth intervals are delineated each transmitting uniform heat. Between 49.51 to $139.95 \mathrm{~mW} \mathrm{~m}^{-2}$ of heat is diverted from vertically reaching the surface by refraction and diffraction, but mainly by hydrologic convection. Similarly, between 10.45 to $18.7 \mathrm{~mW} \mathrm{~m}^{-2}$ of heat is laterally diverted between the bottom and middle intervals. Although thermal conductivity differences between stratas may have some contributions, hydrologic flow is believed to be the major cause. Boreholes discharge of between 12.8 and 1.4 litres $\mathrm{s}^{-1}$ determined for the middle aquifer of the Borno Basin (Yusuf et al., 2014) could result in vertical heat flow disruption of the magnitude encountered.

Three depth intervals each with uniform interval heat flow were delineated within the Kerri Kerri Formation. These diversions of the vertical heat flow between the intervals is believed to result from minor flow of fluid, but largely reflecting thermal conductivity differences with the intervals becoming more sandy with depth. This suggests that the presumed Kerri Kerri Formation at this well site may actually be two formations, with the top two lithologies making up the actual Kerri Kerri Formation, while the lower lithology is the Gombe Formation previously presumed not to have laterally extended far north over the Arage-Marte High toward the Lake Chad. Interval heat flow within the Fika Formation revealed variations that suggest rhymic bedding of lithologies inferred to be shale and sand beds as well as major disruptions attributed to two types of magmatic intrusions. Besides impacting the maturations of organic matter into oil and gas, which depends on their proximities from the source rocks, magmatic intrusions also provide the necessary entrapment structures for capping and sealing the reservoir rocks as well as providing possible migration pathways. The heat injected into host sedimentary strata could also initiate mineralisation of such minerals as illite, magnetite, chalcopyrite, epidote and scheelite from which are mined such elements as tungsten, copper, molybdenum, iron, gold, tin, lead, zinc and silver.

The Gongila and Bima Formations have each two intervals with uniform interval heat flows. The disruption to vertical heat flow within the Gongila Formation is associated with lithological changes arising from the differences between the early deposited sediments that are more sandy from later deposited ones that are more shaley in the late Albian to early Cenomanian marine transgression of the area. Similarly, the disruption within the Bima Formation is believed to be primarily indicative of thermal conductivity change associated with the lithological differences between the more shaley Upper and the more sandy Middle Bima Formations, and secondly to fluid flow within the interstices of the permeable stratas. This implies that reservoir type horizons are more probable within the lower formation, and migration is more probable from source rocks down to reservoirs located below.

The Bullard plots also revealed advections disrupting vertical heat conduction for the same geologic formations in the form of heat carried by lateral flowing fluids in pore spaces, and heat refracted when it obliquely encounters materials of subtle thermal conductivity difference or heat diffracted when it encounters obstacles such as faults. Two such disrupting heat advections were delineated over the heat flowing through basal lithologies for the Chad Formations. The first is also attributed to the convection by flow of fluid, while the second is attributed to both convection and diffraction arising from thermal conductivity differences. Two similar disruptions for the Kerri Kerri Formation were attributed largely to lithology variations between the lower lithology and the two overlying with minor contributions from convection fluids. This also implies that the bottom lithology is more sandy while the middle lithology is more shaley.

The Bullard plot for the Fika Formation revealed five deflections over the flow of heat through the basal lithology which was deposited at early stage of the marine incursion of the area. This lithology is believed to be shaley on account of the comparatively low heat flowing through it. The high advections through three of the five lithologies suggest magmatic intrusions, possessing higher thermal conductivities. The lithologies between the intrusions, on account of their advections, are thought to indicate convections and therefore suggest possible reservoirs. Deflections of the Bullard plots for the Gongila and Bima Formations are both attributed to lithology changes, with that for the Gongila Formation indicating variation from more sandy lithology at the base to more shaley one at the top as the bidirectional marine transgression of the area progressed, while that from the Bima Formation is attributed to the lithology change from the Middle, more sandy, to the Upper, more shaley Bima Formations.

\section{ACKNOWLEDGEMENT}

The authors acknowledge the Nigerian National Petroleum Corporation (NNPC) through the Frontier Exploration Services (FES) for providing the well logs used and for access to invaluable confidential reports on the logs. N. K. Samaila, Department of Geology, A.T.B. University, A. D. Shehu, Department of Physics, A.T.B. University and M. Hassan, Department of Physics, University of Maiduguri are acknowledged for critical reviews of the manuscript. 
REFERENCES

Ali, S., Onuoha, K. M. and Orazulike, D. M., 2003. Estimation of ground surface temperature from meteorological records from Bauchi, NE, Nigeria. Science Forum, 6(2): 276-282.

Ali, S., Onuoha, K. M. and Orazulike, D. M., 2004. Thermal diffusivity estimates in the Chad Basin, NE Nigeria- implications for petroleum exploration. An International Journal of Agricultural Sciences, Sciences, Environment and Technology, Series-B, 3: 155-170.

Ali, S., Onuoha, K. M. and Orazulike, D. M., 2005. Bottomhole temperature correction- the case of the Chad Basin, NE Nigeria. Global Journal of Geosciences, 3(2): 133-142.

Ali, S. and Orazulike, D. M., 2011. Petrophysical parameters of sedimentary formations from the Chad Basin, Nigeria estimated using well log data. Global Journal of Geosciences, 9(2): 143176.

Ali, S., 2016. Assessment of the heat flow and hydrocarbon maturation in the Chad Basin, Northeastern Nigeria. Ph.D. thesis, Department of Physics, Abubakar Tafawa Balewa University, Bauchi, Nigeria.

Allix, P. E., Grosdidier, E., Jardine, S., Legeox, O. and Popoff, M., 1981. Decouverte d'Aptien Superieur a Albun inferieur date par microfossiles dans la serie detritique (Nigeria). Comptes Rendus de l'Academie des Sciences, Serie 11, 292: 12911294.

Armstrong, P. A., Chapman, D. S., Funnell, R. H., Allis, R. G. and Kamp, P. J. J., 1996. Thermal modeling and hydrocarbon generation in an active-margin basin: Taranaki Basin, New Zealand. American Association of Petroleum Geologists Bulletin, 81: 1216-1241.

Avbovbo, A. A., Ayoola, E. O. and Osahon, G. A., 1986. Depositional and structural styles in Chad Basin of northeastern Nigeria. American Association of Petroleum Geologists Bulletin, 80: 1787-1798.

Barber, W. M. and Jones, D. G., 1960. Geology and hydrogeology of Maiduguri, Bornu Province. Records of the Geological Survey of Nigeria, 5 20.

Beardsmore, G.R. and Cull, J.P., 2001. Crustal Heat Flow- A guide to measurement and modeling. Cambridge University Press, Cambridge.

Benkhelil, J. and Robineau, B., 1983. Le fosse de la Benoue est-il un rift. Bulletin of the Centre for Research, Exploration and Production, Elf Aquitaine, 7(1): 315-321.

Bevins, R. E., 1994. Hydrothermal minerals. In: A mineralogy of Wales. National Museum of
Wales, Cardiff. Geological Series no. 16. 146 pp.

Brown, S. R., 1987. Fluid flow through rock joints: Effects of surface roughness. Journal of Geophysical Research, 92: 1337-1347.

Bullard, E. C., 1939. Heat flow in South Africa. Proceedings Royal Society of London. A, 173, $428-450$.

Carter, J. D., Barber, W. and Tait, E. A., 1963. The geology of parts of Adamawa, Bauchi and Bornu Provinces in Northern Nigeria. Geological Survey of Nigeria Bulletin No. 30.

Clemens, J. D. and Mewer, C. K., 1992. Granitic magma transport by fracture propagation. Tectonophysics. 204: 339-360

Clemens, J. D., Petford N. and Mewer, C. K., 1997. Ascend mechanisms of granitic magmas: Causes and consequences. In $M$. Holnes (Editot) Deformation-enhanced fluid transport in the earth's crust and mantle. Chapman and Hall, New York. 144-171

Cratchley, C. R., 1960. Geophysical survey of the southern part of the Chad Basin. CCTA conference on Geology, Kaduna, Northern Nigeria.

Ejedewa, J. E. and Coker, S. J. L., 1984. Dynamic interpretation of organic-matter maturation and evolution of oil-generative window. American Association of Petroleum Geologists Bulletin. 68: $1024-1028$

Esposito, K. J. and Whitney, G., 1995. Thermal effects of thin igneous intrusions on diagenetic reactions in a Tertiary Basin of Southwestern Washington. In S. Y. Johnson (Editor) Evolution of sedimentary basins- Cenozoic sedimentary basins in Southwest Washington and Northwest Oregon. U.S. Geological Survey, Bulletin 2085.

Genik, G. J., 1992. Regional framework, structural and petroleum aspects of rift basins in Niger, Chad and Central African Republic (C.A.R.). Tectonophysics, 213: 169-188.

GeoEngineering International, 1994. Re-appraisal of the hydrocarbon potential of the Nigerian sector of the Chad Basin. National Petroleum Investment Management Services, Nigerian National Petroleum Corporation, Lagos, Nigeria. (Confidential)

Hardee, H. C., 1982. Permeable convection above magma bodies. Tectonophysics, 84: 179-195.

Horner, D. R., 1951. Pressure build-up in wells. Proc. Third World Petroleum Congress, The Hague, $p$. 503. 
Hunt, J. M., Lewan, M. D. and Hennet, R.J-C., 1991. Modeling oil generation with time-temperature index graphs based on the Arrheneius equation. American Association of Petroleum Geologists Bulletin. 75: $795-807$

Huppert, H. and Sparks, R. S. J., 1988. The generation of granitic magmas by intrusion of basalt into continental crust. Journal of Petrology, 29: 599624.

lyer, K., Rüpke, L. and Galerne, C. Y., 2013. Modeling fluid flow in sedimentary basins with sill intrusions: Implications for hydrothermal venting and climate change. Geochemistry, Geophysics, Geosystems, 14: 5244-5262.

Jackson, M. D., Cheadle, M. J. and Atherton, M. P., 2003. Qualitative modeling of granitic melt generation and segregation in the continental crust. Journal of Geophysical Research, 108: 1029-1050.

Jamtveit, B., Svensen, H., Podladchikov, Y. Y. and Planke, S., 2004. Hydrothermal vent complexes associated with sill intrusions in sedimentary basins. Physical Geology of High-Level Magmatic Systems. Geological Society, London, Special Publications, 234, 233 - 241.

Leblanc, Y., Pascoe, L. J. and Jones, F. W. (1981). The temperature stabilization of a bore-hole. Geophysics, 45: 1301-1303.

Mahon, K. I., Harrison, T. M. and Drew, D. A., 1988. Ascend of granitoid diapir in a temperature varying medium. Journal of Geophysical Research, 93: 1174-1188.

Miller, R. E, Johnston, R. H., Olowu, J. A. I. and Uzoma, J. U., 1968. Groundwater hydrogeology of the Chad Basin in Borno and Dikwa Emirates, Northeastern Nigeria, with special emphasis on the flow life of the artesian system. Geological Survey of America, Washington. Paper 1757 1. https://pubs.usgs.gov/wsp/1757i/report.pdf

Obi, G. C., 1996. The origin of the Bama- Maiduguri Ridge complex, Northeastern Nigeria, deduced from pebble form indices, Journal of Mining and Geology, 32(1): 59-64.

Oteze, G. E. and Fayose, E. A., 1988. Regional developments in hydrogeology of the Chad basin water resources. Journal of the Nigerian Association Petroleum Geologists, 66(8): 11411149.

Petford, N., 1996. Dykes or Diapirs? Transactions of the Royal Society of Edinburgh. Earth sciences. 87: $105-114$
Petford, N., Kerr, R. C. and Lister, J. R., 1993. Dike transport of granitoid magmas. Geology. 21: 845-848

Petford, N., Kerr, R. C. and Lister, J. R., 1994. The ascend of felsic magmas in dikes. Lithos. 32 : $161-168$

Reyment, R. A., 1980. Biostratigraphic of the Saharan Cretaceous and Paleocene epicontinental transgression. Cretaceous Research, 1: 299327.

Richter, L, Diamond, L. W., Atanasova, P., Banks, A. D. and Jens Gutzmer, J., 2018. Hydrothermal formation of heavy rare earth element (HREE)xenotime deposits at $100{ }^{\circ} \mathrm{C}$ in a sedimentary basin. Geology, 46(3); 263-266

Samaila, N. K., 2007. Reservoir potentials of the Upper Bima sandstone in the Yola and Lau-Lamurde Basins, Upper Benue trough, NE Nigeria. Unpublished doctoral dissertation, Geology Programme, Abubakar Tafawa Balewa University, Bauchi.

Siever, R., 1983. Burial history and diagenetic reaction kinetics. American Association of Petroleum Geologists Bull. 67: 684-691

Suleiman, A. A., Magee, C., Jackson, C. A.-L. and Fraser, A. J., 2017. Igneous activity in the Bornu Basin, onshore NE Nigeria; implications for opening of the South Atlantic. Journal of the Geological Society, 174 (4). 667 - 678. https://doi.org/10.1144/jgs2016-107

Sydnes, M., Fjeldskaar, W., Grunnaleite, I., Løtveit, I. F. and Mjelde, R., 2019. The influence of magmatic intrusions on diagenetic processes and stress accumulation. Geosciences. 9(477); 1-28. doi:10.3390/geosciences 9110477

Waples, D. W., 1980. Time and temperature in petroleum formation: application of Lopatin's method to petroleum exploration. American Association of Petroleum Geologists Bulletin, 64: 916-926.

Webber, K. L., Simmons, W. B., Falster, A. U. and Foord, E. E., 1999. Cooling rates and crystallization dynamics of shallow level pegmatite-aplite dikes, San Diego County, California. American Mineralogist. 84: 708-717

White, R. and McKenzie, D., 1989. Magmatism at rift zones: the generation of volcanic continental margins and flood basalts. Journal of Geophysical Research. 94, 7685- 7729. 
Wood, D. A., 1988. Relationships between thermal maturity indices calculated using Arrhenius equation and Lopatin method: Implications for petroleum exploration. American Association of Petroleum Geologists Bulletin. 72: 115-134

Yusuf, A. K., Goni, I. B. and Hassan, M., 2014. The declining middle zone aquifer of the SW Chad Basin in the last millennium. IOSR Journal of Applied Geology and Geophysics, 2(2): 67-75.
Zhang, S., Liu, Y. -Q., Li, H., Jiao, X. and Zhou, D. -W., 2020. Hydrothermal-sedimentary dolomite $-\mathrm{a}$ case from the Middle Permian in eastern Junggar Basin, China. Journal of Palaeogeography. $\quad 9(24)$; 1-23. https://doi.org/10.1186/s42501-020-00070-0

Zwaan, J. C., Buter, E., Mertz-Kraus, R. and Kane, R. E., 2015. The Origin of Montana's Alluvial Sapphires. Gems and Gemology. 51(4). 